\title{
A Review on Protective Action of Herbal Drugs Against Fall-Off Libido Due to Chronic Use of B-Blockers(Propranolol)
}

\author{
Mr. Himanshu A. Shingade*, Miss. Janhavi J. Pawar, \\ Dr. Nilofar. S. Naikwade, Mr. Rajkumar S.Gavade, \\ Miss. Snehal S. Jadhav, Mr. Sudhir S. Patil. \\ Appasaheb Birnale College Of Pharmacy Sangli, Maharashtra. India-416416
}

\author{
Corresponding author: \\ Himanshu Arjun Shingade \\ Appasaheb Birnale college of pharmacy, \\ Sangli, Maharashtra. India- 416416 \\ Email id- ashimanshu11@gmail.com
}

\begin{abstract}
From the ancient times human have always tried to correct the sex related problems from various herbal medicinal plants and their extracts with various dosage forms. The history of sex therapy is very old and herbal drugs have been the great reliever as the sex therapy from the evolution of human. Instead of the current scenario with the synthetic compounds the herbal drugs are far more safe and comparatively effective without any serious side effects.
\end{abstract}

Antihypertensives such as $\beta$-blockers can cause the side effects which are responsible for the diminished quality of life. The chronic use of such drugs can be more fatal in some cases than their actual gain. Several sexual problems can occur such as erectile dysfunction, loss of libido, ejaculation disorders etc. The phytochemicals found in the plants which are having aphrodisiac properties shows sildenafil like effect on human body without the side effects of synthetic compound. The pharmaceutically active compounds found in natural aphrodisiacs such as flavonoids, saponins, free amino acids and vitamins are known to be libido enhancer and hence useful in treating sexual disorders. The natural aphrodisiacs can be derived from any source including medicinal plants, vegetables, flowers ,roots or fruits and their pharmacological potential varies as per the part of the plant used.

The target of this review article is to deliver information about medicinal plants for the protective action against fall-off libido due to chronic use of $\beta$-blockers and to investigate for further secondary phytochemicals for aphrodisiac potential.

Keywords: Libido, Aphrodisiacs, $\beta$-blockers, Phytochemicals.

\section{INTRODUCTION:}

Aphrodisiacs are the substances which are used to increase sexual activity and help in fertility. Sexual feelings are an inevitable part of life. The basic and fundamental purpose of sex and sexuality is the "continuation of progeny" and the survival of human race. ${ }^{[1]}$

Infertility is a worldwide medical and social problem. It affects above 10-15\% of married couples. WHO estimates that there are 60-80 million infertile couples worldwide. Infertility in itself may not threaten physical health but it can certainly have a serious impact on the mental and social wellbeing of infertile couple. ${ }^{[1]}$

Herbal medicine plays an important role in rural areas, and several locally produced medicines are still used as home remedies for different ailments. The increasing use of traditional therapies requires stronger scientific evidence for the underlying principles of therapies and for the efficacy of drugs. Herbal medicine remains the mainstay of around $75 \%$ to $80 \%$ of the world's population, mainly in developing countries, for primary health care due to better cultural acceptability, better compatibility with the human body and fewer side effects. Furthermore, traditional knowledge is the most affordable and accessible method available for the treatment of various diseases. ${ }^{[2]}$

Erectile dysfunction, sometimes, which also may imply to refer to "impotence," is the repeated inability to get or keep an erection firm enough for sexual intercourse. ${ }^{[3]}$, On the other hand Coronary arterial diseases are one of the increasingly common chronic diseases around the worldwide. Both selective and non-selective adrenergic receptor blockers, especially selective $\beta 1$-adrenoceptor antagonists, are often used to treat cardiovascular disease, even when complicated by chronic obstructive pulmonary diseases. ${ }^{[4]}$ 
Propranolol is a $\beta 1-\beta 2$ selective receptor blockers. Most studies revealed that propranolol had a histopathologically toxic effect on the testis. Animal model studies showed that propranolol could involve degeneration, necrosis, fibrosis, hypocellularity in germinal epithelium and dystrophic calcification in seminiferous tubules. It is considered that beta blockers impair spermatogenesis via $\beta 2$-receptors.eventually it could cause some sort of sexual dysfunction if taken chronically. ${ }^{[5-6]}$

Sexual dysfunction has a high prevalence among hypertensive men. ${ }^{[7-11]}$ Symptoms of dysfunction include reduced libido, inability to obtain or maintain an erection (impotence), and premature or retarded ejaculation. These symptoms are frequently first reported by patients while receiving antihypertensive therapy, which has lead to a widespread belief that sexual dysfunction is caused by a specific hypotensive agent rather than by hypertension itself. ${ }^{[12]}$

$\beta$-adrenoreceptor blocking drugs have been reported to cause sexual dysfunctions for men. On the other hand, systematically growing evidence from more recent studies shows no co-relation between $\beta$-blocker therapy and sexual function in male patients. ${ }^{[13-15]}$

\section{NATURAL SOLUTIONS WITH APHRODISIAC POTENTIAL :}

Plants with aphrodisiac potential have been used to synthesize many formulations but the phytochemicals present in the plants serves the purpose with less side effects than the synthetic derivatives currently used in the market. Various plants material are well known for their aphrodisiac activity and provides the alternative treatment for sexual dysfunction.Some of the plants having aphrodisiac phytoconstituents are mentioned in below table -

Table no. 1 Showing the List of Plants with Aphrodisiac Potential

\begin{tabular}{|c|c|c|c|c|c|c|c|}
\hline $\begin{array}{l}\text { Sr. } \\
\text { no. }\end{array}$ & Plants & Family & $\begin{array}{l}\text { Common } \\
\text { name }\end{array}$ & pharmacology & $\begin{array}{l}\text { Mech of } \\
\text { action }\end{array}$ & $\begin{array}{l}\text { Chemical } \\
\text { constituents }\end{array}$ & References \\
\hline 1 & $\begin{array}{l}\text { Allium } \\
\text { sativum L }\end{array}$ & Liliaceae & Garlic & $\begin{array}{l}\text { The alcoholic } \\
\text { extract of A. satium } \\
\text { increased sexual } \\
\text { behaviour through } \\
\text { the activities of } \\
\text { sulfated } \\
\text { compounds, } \\
\text { peptides, } \\
\text { flavonoids and } \\
\text { phenolics }\end{array}$ & $\begin{array}{l}\text { Allicin } \\
\text { increases } \\
\text { blood flow } \\
\text { to sexual } \\
\text { organs } \\
\text { through } \\
\text { nitric oxide } \\
\text { synthase }\end{array}$ & $\begin{array}{l}\text { Peptides, } \\
\text { steroids, } \\
\text { terpenes, } \\
\text { flavonoids, } \\
\text { volatile oils and } \\
\text { vitamins }\end{array}$ & {$[16],[17]$} \\
\hline 2. & $\begin{array}{l}\text { Alpinia } \\
\text { galangal } \mathrm{L}\end{array}$ & $\begin{array}{l}\text { Zingiberac } \\
\text { eae }\end{array}$ & $\begin{array}{l}\text { Galangal, } \\
\text { blue ginger, } \\
\text { Thai ginger }\end{array}$ & $\begin{array}{l}\text { Methnaolic extract } \\
\text { of A. galangal } \\
\text { showed increase in } \\
\text { serum testosterone } \\
\text { levels at } 300 \\
\mathrm{mg} / \mathrm{kg} / \text { day }\end{array}$ & - & $\begin{array}{l}\text { Coumarin, } \\
\text { terpenoids, } \\
\text { flavonoids, } \\
\text { volatile oils, } \\
\text { Phenols }\end{array}$ & {$[16],[17]$} \\
\hline
\end{tabular}




\begin{tabular}{|c|c|c|c|c|c|c|c|}
\hline 3 & $\begin{array}{l}\text { Anacardium } \\
\text { ocidentale } \mathrm{L} .\end{array}$ & $\begin{array}{l}\text { Anacardia } \\
\text { ceae }\end{array}$ & Cashew & $\begin{array}{l}\text { In a study to } \\
\text { determine } \\
\text { the aphrodisiac } \\
\text { activity of the oils } \\
\text { from Anacardium } \\
\text { ocidentale L seeds } \\
\text { and shell, the } \\
\text { result showed } \\
\text { significant increase } \\
\text { in sexual } \\
\text { parameters }\end{array}$ & 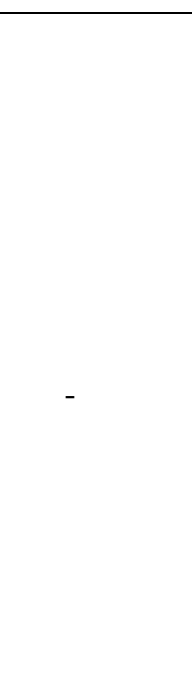 & $\begin{array}{l}\text { Carbohydrates, } \\
\text { phenols, } \\
\text { flavonoids, } \\
\text { steroids, } \\
\text { proteins }\end{array}$ & {$[16],[17]$} \\
\hline 4 & $\begin{array}{l}\text { Cannabis } \\
\text { sativa } L\end{array}$ & $\begin{array}{l}\text { Cannabina } \\
\text { ceae }\end{array}$ & $\begin{array}{l}\text { Marijuana, } \\
\text { hemp }\end{array}$ & $\begin{array}{l}\text { In India's ayurveda } \\
\text { and Chinese unani } \\
\text { medicine, } \\
\text { Cannabisis used to } \\
\text { overcome } \\
\text { impotence and } \\
\text { raise libido and as } \\
\text { a general cure for } \\
\text { the disease. }\end{array}$ & - & $\begin{array}{l}\text { Cannabinoids, } \\
\text { Phenol, } \\
\text { alkaloid, } \\
\text { flavonoid, } \\
\text { volatile oils }\end{array}$ & {$[16],[17]$} \\
\hline 5 & $\begin{array}{l}\text { Chlorophylu } \\
m \\
\text { borivilianum }\end{array}$ & Liliaceae & Safed Musli & $\begin{array}{l}\text { In a study of the } \\
\text { aqueous extract of } \\
\text { dried roots of Safed } \\
\text { Musli in rats, there } \\
\text { was increase in } \\
\text { libido, sexual } \\
\text { vigour and sexual } \\
\text { arousal at } 250 \\
\text { mg/kg. The sudy } \\
\text { supported } \\
\text { treatment of } \\
\text { premature } \\
\text { ejaculation and } \\
\text { oligospermia }\end{array}$ & $\begin{array}{l}\text { The } \\
\text { chemical } \\
\text { structure of } \\
\text { stigmasterol } \\
\text { is related to } \\
\text { that of } \\
\text { testosterone } \\
\text { and mainly } \\
\text { contributes } \\
\text { to its } \\
\text { aphrodisiac } \\
\text { potentials; } \\
\text { hecogenin } \\
\text { produces } \\
\text { anabolic } \\
\text { hormone }\end{array}$ & $\begin{array}{l}\text { glycosides, } \\
\text { saponins, fatty } \\
\text { acids, } \\
\text { hydrocarbons }\end{array}$ & {$[16],[17]$} \\
\hline
\end{tabular}




\begin{tabular}{|c|c|c|c|c|c|c|c|}
\hline 6 & $\begin{array}{l}\text { Citrulllus } \\
\text { lanatus } \\
\text { (Thunb.) } \\
\text { Matsum. \& } \\
\text { Nakai }\end{array}$ & $\begin{array}{l}\text { Cucurbitac } \\
\text { eae }\end{array}$ & $\begin{array}{l}\text { Water } \\
\text { Melon }\end{array}$ & $\begin{array}{l}\text { The effect of red } \\
\text { watermelon flesh } \\
\text { extract on male } \\
\text { sexual behaviour } \\
\text { has been } \\
\text { determined. In the } \\
\text { research, the } \\
\text { suspension of the } \\
\text { flesh extract was } \\
\text { administered on } \\
\text { doses } 100,500 \text { and } \\
\text { 1000 mg/kg to } \\
\text { different groups of } \\
\text { male rats (n=5) } \\
\text { daily for } 22 \text { days. } \\
\text { The result showed } \\
\text { that oral } \\
\text { administration of } \\
\text { watermelon flesh } \\
\text { extract caused } \\
\text { significant increase } \\
\text { in mounting } \\
\text { frequency, } \\
\text { intromission } \\
\text { frequency and } \\
\text { ejaculatory latency. } \\
\text { Watermelon flesh } \\
\text { extract did not } \\
\text { produce } \\
\text { undesirable side } \\
\text { effects on the male } \\
\text { rats and thus its } \\
\text { short term use is } \\
\text { apparently safe }\end{array}$ & $\begin{array}{l}\text { Citrulline } \\
\text { improves } \\
\text { blood drive } \\
\text { to the } \\
\text { genital } \\
\text { regions and } \\
\text { plays a } \\
\text { significant } \\
\text { role in the } \\
\text { relaxation of } \\
\text { blood, a } \\
\text { major tool in } \\
\text { high sexual } \\
\text { performance }\end{array}$ & Carotenoids & {$[16],[17]$} \\
\hline 7 & $\begin{array}{l}\text { Myristica } \\
\text { fragrans } \\
\text { Houtt }\end{array}$ & $\begin{array}{l}\text { Myristacea } \\
\text { e }\end{array}$ & Nutmeg & $\begin{array}{l}50 \% \text { ethanolic } \\
\text { extract showed } \\
\text { significant increase } \\
\text { in aphrodisiac } \\
\text { properties in mice }\end{array}$ & $\begin{array}{l}\text { Stimulation } \\
\text { of the } \\
\text { nervous } \\
\text { system by } \\
\text { myristicin }\end{array}$ & $\begin{array}{l}\text { Essential oils, } \\
\text { fixed oils, } \\
\text { unsaturated } \\
\text { aliphatic } \\
\text { hydrocarbon }\end{array}$ & {$[16],[17]$} \\
\hline
\end{tabular}




\begin{tabular}{|c|c|c|c|c|c|c|c|}
\hline & & & & $\begin{array}{l}\text { such as increase in } \\
\text { mating frequency, } \\
\text { libido and potency. } \\
\text { It has also been } \\
\text { used in Unani } \\
\text { medicine for the } \\
\text { treatment of sexual } \\
\text { disorders }\end{array}$ & & & \\
\hline 8 & $\begin{array}{l}\text { Passiflora } \\
\text { incarnate L. }\end{array}$ & $\begin{array}{l}\text { Passiflorac } \\
\text { eae }\end{array}$ & $\begin{array}{l}\text { Passion } \\
\text { flower }\end{array}$ & $\begin{array}{l}\text { The aphrodisiac } \\
\text { effect of the } \\
\text { methanolic extract } \\
\text { of } P \text {. incarnate } \mathrm{L} \\
\text { has been } \\
\text { determined in } \\
\text { mice. The result } \\
\text { showed significant } \\
\text { aphrodisiac } \\
\text { properties in male } \\
\text { mice at all doses- } \\
75,100 \text { and } 150 \\
\mathrm{mg} / \mathrm{kg} \text { with } 100 \\
\mathrm{mg} / \mathrm{kg} \text { having the } \\
\text { highest activity }\end{array}$ & & $\begin{array}{l}\text { Phenolics, } \\
\text { alkaloids, } \\
\text { sugars }\end{array}$ & {$[16],[17]$} \\
\hline 9 & $\begin{array}{l}\text { Pedalium } \\
\text { murex } L\end{array}$ & $\begin{array}{l}\text { Pedaliacea } \\
\text { e }\end{array}$ & $\begin{array}{l}\text { Caltrops, } \\
\text { Gokhru }\end{array}$ & $\begin{array}{l}\text { In a study against } \\
\text { ethanol induced } \\
\text { infertility in male } \\
\text { rats } 200 \mathrm{mg} / \mathrm{kg} \text { and } \\
400 \mathrm{mg} / \mathrm{kg} \text { of } \\
\text { petroleum ether } \\
\text { extracts showed } \\
\text { significant increase } \\
\text { in mating, } \\
\text { mounting } \\
\text { behaviour, total } \\
\text { body weight, sperm } \\
\text { motility and } \\
\text { percentage of } \\
\text { pregnancy }\end{array}$ & $\begin{array}{l}\text { increase in } \\
\text { sexual } \\
\text { behaviour }\end{array}$ & $\begin{array}{l}\text { Saponins, } \\
\text { flavonoids, } \\
\text { amino acids and } \\
\text { fatty acids }\end{array}$ & {$[16],[17]$} \\
\hline
\end{tabular}




\begin{tabular}{|c|c|c|c|c|c|c|c|}
\hline 10 & $\begin{array}{l}\text { Mucuna } \\
\text { pruriens } L\end{array}$ & $\begin{array}{l}\text { Leguminos } \\
\text { ae }\end{array}$ & Devil beans & $\begin{array}{l}\text { In different texts of } \\
\text { ayurveda, } M \text {. } \\
\text { pruriens is most } \\
\text { commonly used in } \\
\text { aphrodisiac } \\
\text { formulations. At } 70 \\
\text { mg/kg, treatments } \\
\text { significantly } \\
\text { improved } \\
\text { testosterone } \\
\text { quality, } \\
\text { ameliorated } \\
\text { psychological } \\
\text { stress and } \\
\text { improved sperm } \\
\text { count }\end{array}$ & $\begin{array}{l}\text { Producing a } \\
\text { dose- } \\
\text { dependent } \\
\text { increase in } \\
\text { follicle } \\
\text { stimulating } \\
\text { hormone } \\
\text { and } \\
\text { leutenizing } \\
\text { hormone } \\
\text { which } \\
\text { increases the } \\
\text { number of } \\
\text { eggs } \\
\text { released at } \\
\text { ovulation by } \\
\text { the action of } \\
\text { L-DOPA } \\
\text { and } \\
\text { dopamine }\end{array}$ & $\begin{array}{l}\text { Alkaloids, } \\
\text { amino acids, } \\
\text { saponins, } \\
\text { vitamins }\end{array}$ & {$[16],[17]$} \\
\hline
\end{tabular}

\section{CONCLUSION:}

Nowadays there are more and more interests worldwide taken in herbal medicines accompanied with increased laboratory investigations into the pharmacological properties of the bioactive ingredients and their ability to treat various diseases. The present review has accentuated on the effects of Natural aphrodisiacs, the aphrodisiac phytoconstituents present in the plants, the various biochemical estimations and several in-vitro, invivo and human studies. The brief survey of literature evidences shows us that the traditional herbal therapies have no known side effects in the presence of aphrodisiac phytoconstituents in plant extracts.

\section{REFERENCES:}


1. Wani JA, Achur RN, Nema RK. Phytochemical screening and aphrodisiac activity of Asparagus racemosus. International Journal of Pharmaceutical sciences and drug Research. 2011;3(2):112-5.

2. Vidyarthi S, Samant SS, Sharma P. Traditional and indigenous uses of medicinal plants by local residents in Himachal Pradesh, North Western Himalaya, India. International Journal of Biodiversity Science, Ecosystem Services \& Management. 2013 Sep 1;9(3):185-200.

3. Ramandeep Singh, Ashraf Ali, G. Jeyabalan, Alok Semwal, Jaikishan. An overview of the current methodologies used for evaluation of aphrodisiac agents. Journal of Acute Disease. 2013 85-91-ELSEVIER

4. Zhou Y, Xu M, Zhang Y, Guo Y, Zhang Y, He B. Effects of long-term application of metoprolol and propranolol in a rat model of smoking. Clinical Experimental Pharmacology Physiology. 2014;41(9):708-15.

5. (Martinez D, Barthe D. Histological study of the action of propranolol on the genital tract of the male rat. Acta anatomica. 1980;109(4):346-54. )

6. ( Liaqat Ali AKN, Liaqat Ali M, Tahir M. Effects of the propranolol on morphology of adult rats testis. Inter J Pathol. 2008;6(1):19-22. )

7. Bansal S: Sexual dysfunction in hypertensive men. A criticalreview of the literature. Hypertension 1988, 12:1-10.

8. Bulpitt CJ, Dollery CT, Carne S: Changes in symptoms of hypertensive patients after referral to hospital clinic. Br Heart J 1976, 38:121-128.

9. Bauer GE, Hunyor SN, Baker J, Marshall P: Clinical side effect of antihypertensive treatment: a placebo-controlled, doubleblind study. Postgrad Med Comm (Special report) 1981, 49-54.

10. Croog SH, Levine S, Sudilovsky A, et al.: Sexual symptoms in hypertensive patients. A clinical trial of antihypertensive medications. Arch Intern Med 1988, 148:788-794.

11. Jensen J, Lendorf A, Stimpel H, et al.: The prevalence and etiology of impotence in 101 male hypertensive outpatients. Am J Hypertens 1999, 12:271-275.

12. Fogari R, Zoppi A. Effects of antihypertensive therapy on sexual activity in hypertensive men. Current Hypertension Reports. 2002 May 1;4(3):202-10.

13. Weiss RJ. Effects of antihypertensive agents on sexual function.Am Fam Physician 1991; 44: 2075-2082. 
14. Fogari R, Preti P, Derosa G, Marasi G, Zoppi A, Rinaldi A et al.Effect of antihypertensive treatment with valsartan or atenololon sexual activity and plasma testosterone in hypertensivemen. Eur J Clin Pharmacol 2002; 58: 177-180.

15. Fogari R, Zoppi A, Poletti L, Marasi G, Mugellini A, Corradi L.Sexual activity in hypertensive men treated with valsartanor carvedilol: a crossover study. Am J Hypertens 2001; 14:27-31.)

16. Yakubu MT, Akanji MA, Oladiji AT. Male sexual dysfunction and methods used in assessing medicinal plants with aphrodisiac potentials. Pharmacognosy Reviews. 2007;1(1).

17. Singh B, Gupta V, Bansal P, Singh R, Kumar D. Pharmacological potential of plant used as aphrodisiacs. International Journal of Pharmaceutical Sciences Review and Research. 2010 Nov;5(1):104-13. 